\title{
ANALISA STRATEGI E-MARKETING DAN IMPLEMENTASINYA PADA RENTAL COMPANY
}

\author{
Meyliana \\ Jurusan Sistem Informasi, Fakultas Ilmu Komputer, Bina Nusantara University \\ Jl. K.H. Syahdan No. 9, Kemanggisan, Palmerah, Jakarta Barat 11480 \\ meyliana@binus.edu
}

\begin{abstract}
Customers are the main key for persistence of a company. The company could arrange old customers and attract new customers, as marketing event. Marketing is one component in customer relationship management. Marketing today has become a trend in doing promotion, increase new customers to expand target market, and maintain old customer loyalty to increase the company sales' point volume. Supported by appropriate information technology, marketing event could be changed as events that give benefit to the company. Marketing event with information technology, e-marketing, is done to increase company image. After being analysed, this e-marketing strategy will be implemented to rental company.
\end{abstract}

Keywords: e-marketing, e-marketing strategy, rental company

\begin{abstract}
ABSTRAK
Pelanggan merupakan kunci utama bagi keberlangsungan suatu perusahaan. Perusahaan harus dapat mengelola pelanggan lama dan menarik pelanggan baru: kegiatan pemasaran. Pemasaran merupakan salah satu komponen dalam ilmu Manajemen Hubungan Pelanggan (Customer Relationship Management). Pemasaran saat ini telah menjadi tren untuk melakukan promosi, meningkatkan jumlah pelanggan baru untuk memperluas pasar, dan mempertahankan loyalitas pelanggan lama untuk meningkatkan volume penjualan perusahaan. Dengan bantuan teknologi informasi yang sesuai, kegiatan pemasaran dapat diubah menjadi kegiatan yang sangat menguntungkan perusahaan. Kegiatan pemasaran dengan bantuan teknologi informasi, emarketing, dilakukan untuk meningkatkan image perusahaan. Setelah dianalisa, strategi e-Marketing ini akan diimplementasikan pada perusahaan yang memiliki jenis usaha penyewaan.
\end{abstract}

Kata kunci: e-marketing, strategi e-marketing, perusahaan penyewaan 


\section{PENDAHULUAN}

Perkembangan internet yang sangat cepat sangat mempengaruhi perubahan bisnis. Banyak aktivitas bisnis yang berubah dengan tersedianya internet saat ini. Perubahan aktivitas bisnis yang signifikan dipengaruhi oleh internet salah satunya adalah pemasaran/marketing. Pemasaran adalah proses sosial dan manajerial dimana individu dan grup memperoleh apa yang mereka inginkan dan butuhkan melalui penciptaan dan pertukaran produk dan nilai dengan orang lain (Kotler \& Amstrong, 2004). Pemasaran juga merupakan proses dari perancangan dan pelaksanaan konsepsi, harga, promosi dan distribusi dari ide, barang dan layanan untuk menciptakan pertukaran yang memuaskan individu dan tujuan organisasi (Mohammed et al., 2003). Konsep internet yang tidak memiliki batasan tempat dan waktu, semakin memudahkan perusahaan dalam memberikan informasi produknya. Sistem pemasaran produk melalui internet ini lebih sering didengar dengan istilah e-marketing. E-marketing menggambarkan usaha-usaha perusahaan untuk menginformasikan, berkomunikasi, mempromosikan dan memasarkan produk dan jasa melalui internet (Kotler \& Armstrong, 2004). Electronic marketing memanfaatkan teknologi jaringan untuk mengkoordinasi penelitian pangsa pasar, membantu pengembangan produk, mengembangkan strategi dan taktik untuk memikat pelanggan, menyediakan distribusi online, mempertahankan catatan pelanggan, menciptakan kepuasan pelanggan, dan mengumpulkan umpan balik pelanggan (Reedy, Schullo \& Zimmerman, 2000).

E-marketing merupakan bagian dari $e$-commerce yang merupakan sistem perdagangan melalui internet, di mana internet akan terus memberikan sifat yang up to date, maka perusahaan dapat memberikan layanan informasi produk yang ditawarkan secara jelas dan mudah. Hal ini akan memberikan dampak yang baik untuk kemajuan perusahaan jika sistem ini bisa dijalankan dengan baik. Selain itu e-marketing juga merupakan bagian dari e-CRM dimana pengelolaan hubungan dengan pelanggan salah satunya melalui kegiatan pemasaran. E-marketing banyak dilakukan untuk meningkatkan brand image perusahaan karena membuat perusahaan selalu diingat oleh pelanggannya (top of mind). E-marketing banyak memberikan kemudahan dan keuntungan lebih bagi perusahaan, pelanggan dan rekanan bisnis dari perusahaan. Pemilihan strategi $e$ - marketing yang cocok dengan perusahaan dan mengetahui detil cara dan dampak penerapannya sangat penting dan diperlukan oleh perusahaan.

Perusahaan yang dipilih dalam penelitian ini adalah perusahaan penyewaan (PT Princess Sound System). PT Princess Sound System adalah perusahaan penyewaan di Jakarta yang bergerak di bidang sound system, laser, lighting, equipment DJ, audio visual, ringging \& stage, untuk kebutuhan penyelenggaraan event seperti music concert, launching product, company gathering, live broadcast televison, fashion show atau road show, pernikahan atau acara ulang tahun, pameran, mobile disco, dan lain-lain. Masalah yang dihadapi oleh PT Princess Sound System adalah penyebaran informasi hanya terbatas pada para pelanggan tetap sehingga perlu dikembangkan suatu aplikasi pemasaran berbasis web yang dapat memperluas jangkauan pasar dan menarik para pelanggan baru. Selain itu, bidang perekonomian yang ketat persaingannya sekarang ini, memerlukan adanya sistem pemasaran yang baik dan tepat untuk menunjang aktivitas penyewaan yang memegang peranan penting dalam perusahaan ini, karena aktivitas inilah yang menjembatani antara pelanggan dengan perusahaan dan yang menentukan tingkat perkembangan di perusahaan. Kendala-kendala yang ditemukan dalam pemasaran dan pemesanan dalam PT Princess Sound System adalah sulitnya mendapatkan informasi yang detail mengenai produk-produk yang disewakan dan daerah pemasaran yang kurang luas.

Tujuan penelitian ini untuk menganalisa strategi pemasaran yang berjalan dan bagaimana mentransformasinya menjadi e-marketing serta bagaimana mengimplementasinya di dalam perusahaan. Sedangkan manfaat yang didapat dengan penelitian ini adalah perusahaan dapat memperluas jangkauan pemasaran, meningkatkan hubungan dengan pelanggan yang sudah ada, dan memperoleh calon pelanggan baru. 


\section{Metode Penelitian}

Penelitian ini dilakukan dalam bentuk menganalisa dan mendesain strategi e-marketing berdasarkan 7 tahapan dari Judy Strauss (Strauss \& Frost, 2009) yaitu situation analysis (analisis situasi), e-marketing strategic planning (strategi perencanaan e-marketing), objectives (tujuan), $e$ marketing strategy (strategi e-marketing), implementation plan (implementasi perencanaan), budget (anggaran), dan evaluation plan (rencana evaluasi).

\section{Analisis Situasi}

Tahap pertama merupakan awal dari konsep bisnis dengan melakukan analisis kekuatan, peluang, kelemahan serta ancaman bagi perusahaan. Dalam bagian ini, analisis situasi yang digunakan adalah analisis SWOT. Menurut Rangkuti (2004), analisis SWOT adalah indentifikasi berbagai faktor secara sistematis untuk merumuskan strategi perusahaan. Analisis ini disarankan pada logika yang dapat memaksimalkan kekuatan (strengths) dan peluang (opportunities), namun secara bersamaan dapat meminimalkan kelemahan (weaknesses) dan ancaman (threats). Proses pengambilan keputusan strategi selalu berkaitan dengan pengembangan misi, tujuan, strategi, dan kebijakan perusahaan. Dengan demikian perencanaan strategi harus menganalisis faktor-faktor strategi perusahaan (kekuatan, kelemahan, peluang, dan ancaman) dalam kondisi yang ada saat ini. Hal ini disebut analisis situasi. Analisis SWOT membandingkan antara faktor internal kekuatan (strengths) dan kelemahan (weaknesses) dengan faktor eksternal peluang (opportunities) dan ancaman (threats) yang dihadapi dunia bisnis.

Tabel 1 Kerangka Formulasi Strategis (Rangkuti, 2004)

\begin{tabular}{|c|c|c|c|c|}
\hline $\begin{array}{c}\text { Matrik Faktor } \\
\text { Eksternal }\end{array}$ & 1. & $\begin{array}{l}\text { Pengumpulan Data } \\
\text { Matrik Faktor } \\
\text { Internal }\end{array}$ & & $\begin{array}{l}\text { Matrik Profil } \\
\text { Kompetitif }\end{array}$ \\
\hline $\begin{array}{c}\text { Matrik } \\
\text { TOWS/SWOT }\end{array}$ & $\begin{array}{c}\text { Matrik } \\
\text { BCG }\end{array}$ & $\begin{array}{l}\text { Tahap Analisis } \\
\text { Matrik } \\
\text { Internal Eksternal }\end{array}$ & $\begin{array}{l}\text { Matrik } \\
\text { SPACE }\end{array}$ & $\begin{array}{r}\text { Matrik } \\
\text { Grand Strategy }\end{array}$ \\
\hline \multicolumn{5}{|c|}{$\begin{array}{l}\text { 3. Tahap Pengambilan Keputusan } \\
\text { Matrik Perencanaan Strategi Kuantitatif } \\
\text { (Quantitave Strategic Planning Matrix) (QSPM) }\end{array}$} \\
\hline
\end{tabular}

\section{Strategi Perencanaan E-marketing}

Dalam tahap ini terdapat metodologi tujuh langkah sederhana yang membantu dalam mengevaluasi dan menganalisis peluang pasar (Market Opportunity Analysis/MOA), yaitu:

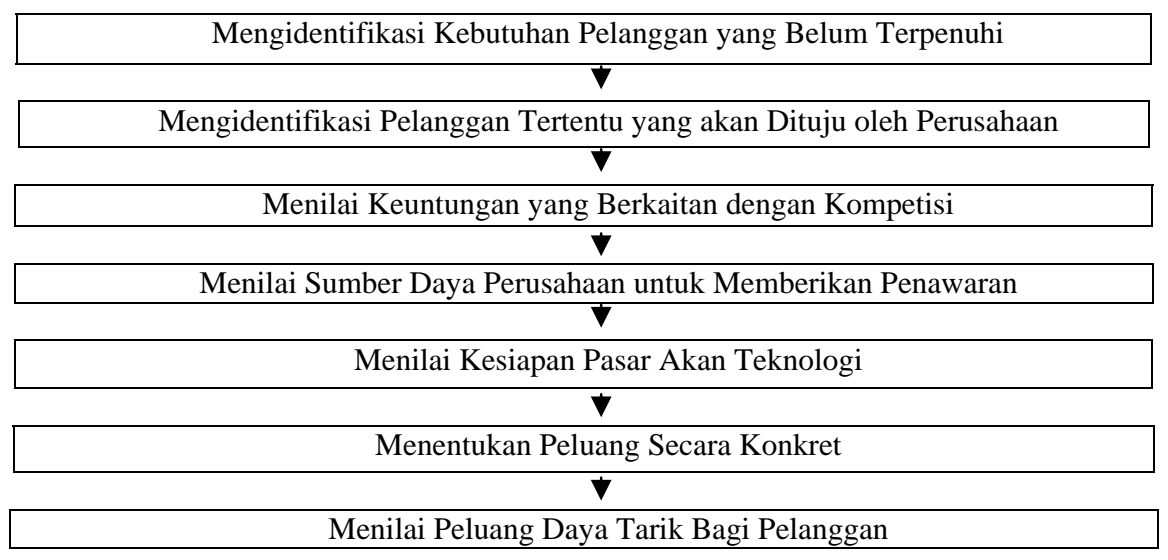

Gambar 1 Kerangka Kerja Peluang Pasar (Rayport dan Jaworski, 2003) 
Strategi perencanaan e-marketing meliputi segmentasi, sasaran, diferensiasi, dan posisi.

\section{Tujuan}

Tujuan dalam e-marketing mencakup aspek: tugas, apa yang akan dicapai; kuantitas yang terukur, seberapa banyak; time frame, kapan. Sebagian besar e-marketing bertujuan untuk mencapai berbagai tujuan, seperti: (1) meningkatkan pangsa pasar; (2) meningkatkan jumlah komentar pada sebuah blog atau website; (3) meningkatkan pendapatan penjualan; (4) mengurangi biaya, misalnya biaya distribusi atau promosi; (5) mencapai tujuan merek, seperti meningkatkan kesadaran merek; (6) meningkatkan ukuran database; (7) mencapai tujuan Customer Relationship Management, seperti meningkatkan kepuasan pelanggan, frekuensi pembelian, atau tingkat referensi pelanggan; (8) memperbaiki manajemen rantai suplai, seperti dengan meningkatkan koordinasi anggota, menambahkan mitra, atau mengoptimalkan tingkat persediaan.

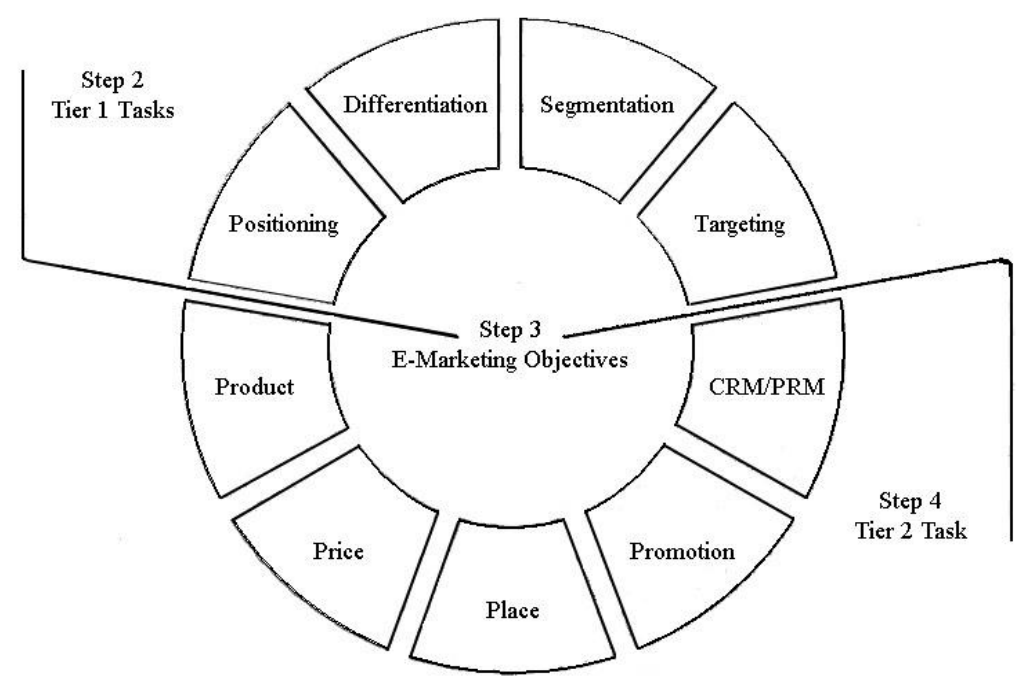

Gambar 2 E-Marketing Plan (Strauss dan Frost, 2009)

\section{Strategi E-marketing}

Strategi e-marketing mencakup strategi mengenai 4P dan hubungan manajemen untuk mencapai tujuan rencana mengenai product (produk), price (harga), place (saluran distribusi), dan promotion (promosi).

\section{Rencana Pelaksanaan}

Pada tahap ini perusahaan memutuskan bagaimana untuk mencapai tujuan melalui strategi yang efektif dan kreatif. Pemasar memilih bauran pemasaran (4 P), strategi manajemen dan strategi lain untuk mencapai tujuan rencana dan kemudian menyusun rencana pelaksanaan. Perusahaan juga memeriksa untuk memastikan organisasi pemasaran yang tepat di tempat pelaksanaan (staf, struktur departemen, penyedia layanan aplikasi, dan lain-lain di luar perusahaan). Internet telah mengubah tempat pertukaran dari marketplace (seperti, interaksi face-to-face) menjadi marketspace (seperti, interaksi screen-to-face). Perbedaan utama adalah bahwa sifat hubungan pertukaran sekarang ditengahi oleh interface teknologi. Dengan perpindahan dari hubungan antarmuka people-mediated menjadi technology-mediated, terdapat sejumlah pertimbangan perancangan interface yang dihadapi. 
Menurut Rayport \& J.Jaworski. (2003), ada berbagai elemen dalam mendesain sebuah situs web, yaitu context (konteks dari situs mencerminkan nilai keindahan dan kegunaan dari situs tersebut), content (konten merupakan semua objek digital yang terdapat dalam sebuah web baik dalam bentuk audio, video, image ataupun text), community (komunitas merupakan ikatan hubungan yang terjadi antara sesama pengunjung atau pelanggan dari sebuah website karena adanya kesamaan minat atau hobi), customization (kustomisasi merupakan kemampuan situs untuk memodifikasi dirinya sesuai dengan keinginan penggunanya), communication (komunikasi antara perusahaan dengan pelanggan, terdiri dari Broadcast Dimension, Interactive Dimension, dan Hybrid Dimension), connection (kemampuan sebuah website untuk berpindah dari sebuah webpage ke webpage lainnya ataupun website lainnya dengan on-click baik pada text, images maupun toolbars yang lain), dan commerce (commerce merupakan fitur dari customer interface yang mendukung berbagai aspek dari transaksi perdagangan dan memiliki dimensi seperti registration, shopping cart, security, credit card approval, one click shopping, order through affiliates, configuration technology, order tracking, delivery option).

\section{Anggaran}

Kunci dari perencanaan strategis adalah untuk mengidentifikasi hasil yang diharapkan dari suatu investasi. Selama pelaksanaan rencana, pemasar akan terus memantau pendapatan aktual dan biaya untuk melihat hasil yang telah dicapai. Internet merupakan salah satu tools yang dapat digunakan untuk memantau hasil karena catatan teknologi pengunjung setiap klik. Untuk mendapatkan informasi anggaran yang dapat dipertanggungjawabkan, perlu dibuat perhitungan tentang revenue forecast (perkiraan pendapatan), intangible benefits (manfaat tidak berwujud), cost savings (penghematan biaya), dan $e$-marketing costs (biaya e-marketing).

\section{Rencana Evaluasi}

Perencanaan e-marketing dilaksanakan, keberhasilannya tergantung pada evaluasi yang terusmenerus. Jenis evaluasi ini tergantung pada tujuan rencana. Untuk menentukan hasil pemasarannya, perusahaan dapat menggunakan balanced scorecard untuk mengukur kesuksesan dari program internet marketing dan apakah program internet marketing tersebut cocok sesuai dengan objektif dari perusahaan.

\section{HASIL DAN PEMBAHASAN}

\section{Analisis Situasi}

PT Princess Sound System adalah perusahaan penyewaan di Jakarta yang bergerak di bidang sound system, laser, lighting, equipment DJ, audio visual, rigging dan stage, untuk kebutuhan penyelenggaraan acara seperti : konser musik, peluncuran produk, company gathering, live broadcast television, fashion show atau road show, acara pernikahan atau ulangtahun, pameran, mobile disco, dan lainnya. Saat ini PT. Princess Sound System telah memiliki jaringan kerja sama yang luas seperti: (1) stasiun televisi: Trans TV, SCTV, Indosiar, ANTV, Trans 7; (2) production house: Multivision, MD Entertainment, Cinema Art; (3) mall: Taman Anggrek, Ciputra, Plaza Senayan, Pondok Indah, La Piazza Kelapa Gading, Cilandak Town Square dan Puri Indah; (4) bridal/modelling : King Foto, Tina Andrean, Sophia, Cantik, Yohanes, Ricky L, Looks Model, OQ Modelling, Grisvian Hewis, Cucu, APPMI; (5) event organizer: Vietara, Bagus Integrated, Mitra Adi Perkasa, Level 9, 2 Sinergi, WOW Communindo, Deteksi, Jak Jazz; (6) property: Sinar Mas Group, Summarecon, Agung Sedayu. Untuk analisa SWOT dapat dilihat pada Tabel 1 dan strategi yang diambil adalah strategi SO. 


\begin{tabular}{|c|c|c|}
\hline & $\begin{array}{l}\text { Kekuatan (Strength) } \\
\text { 1. Menawarkan produk dengan } \\
\text { kualitas yang baik } \\
\text { 2. Pelayanan merupakan prioritas } \\
\text { perusahaan untuk memberikan } \\
\text { kepuasan bagi konsumen } \\
\text { 3. Decision maker } \\
\text { 4. Memiliki hubungan kerjasama } \\
\text { dengan banyak pihak }\end{array}$ & $\begin{array}{l}\text { Kelemahan (Weakness) } \\
\text { 1. Brand image yang belum } \\
\text { terkenal } \\
\text { 2. Proses pemasaran masih } \\
\text { mengandalkan word of mouth } \\
\text { 3. Tidak memanfaatkan } \\
\text { teknologi informasi secara } \\
\text { maksimal } \\
\text { 4. Daerah pemasaran kurang } \\
\text { luas }\end{array}$ \\
\hline $\begin{array}{l}\text { Peluang (Opportunity) } \\
\text { 1. Peningkatan jumlah } \\
\text { pengguna internet di } \\
\text { Indonesia } \\
\text { 2. Peluang pasar masih banyak } \\
\text { yang belum terjangkau } \\
\text { 3. Teknologi membantu } \\
\text { perusahaan dalam usaha } \\
\text { pemasaran } \\
\text { 4. Adanya tren pemasaran } \\
\text { melalui internet }\end{array}$ & $\begin{array}{l}\text { Strategi SO } \\
\text { 1. Memperluas daerah pemasaran } \\
\text { untuk meningkatkan jumlah } \\
\text { pelanggan } \\
\text { 2. Memelihara kualitas dan mutu } \\
\text { pelayanan } \\
\text { 3. Mempererat hubungan kerja sama } \\
\text { dengan pelanggan tetap } \\
\text { 4. Mengembangkan pemasaran } \\
\text { dengan merancang web e- } \\
\text { marketing }\end{array}$ & $\begin{array}{l}\text { Strategi WO } \\
\text { 1. } \quad \text { Memanfaatkan teknologi } \\
\text { secara optimal untuk } \\
\text { mendukung operasional dan } \\
\text { pemasaran perusahaan }\end{array}$ \\
\hline $\begin{array}{l}\text { Ancaman (Threat) } \\
\text { 1. Persaingan usaha yang } \\
\text { semakin banyak } \\
\text { 2. Munculnya pendatang baru } \\
\text { yang potensial }\end{array}$ & $\begin{array}{l}\text { Strategi ST } \\
\text { 1.Mempertahankan reputasi dengan } \\
\text { memberikan produk berkualitas } \\
\text { terbaik. } \\
\text { 2.Memberikan layanan yang bersaing } \\
\text { dengan kompetitor. }\end{array}$ & $\begin{array}{l}\text { Strategi WT } \\
\text { 1. Melakukan kegiatan promosi } \\
\text { yang lebih gencar }\end{array}$ \\
\hline
\end{tabular}

Berdasarkan matrik Internal dan Eksternal (Gambar 3), dengan nilai total skor IFAS=2.45 dan EFAS=3.00 tampak bahwa PT. Princess Sound System berada pada sel II, yaitu dimana perusahaan berada dalam posisi Pertumbuhan dan Membangun. Artinya, PT. Princess Sound System dapat memperluas strategi bisnisnya dengan memperluas lokasi pemasaran, dan meningkatkan jenis produk serta jasa.

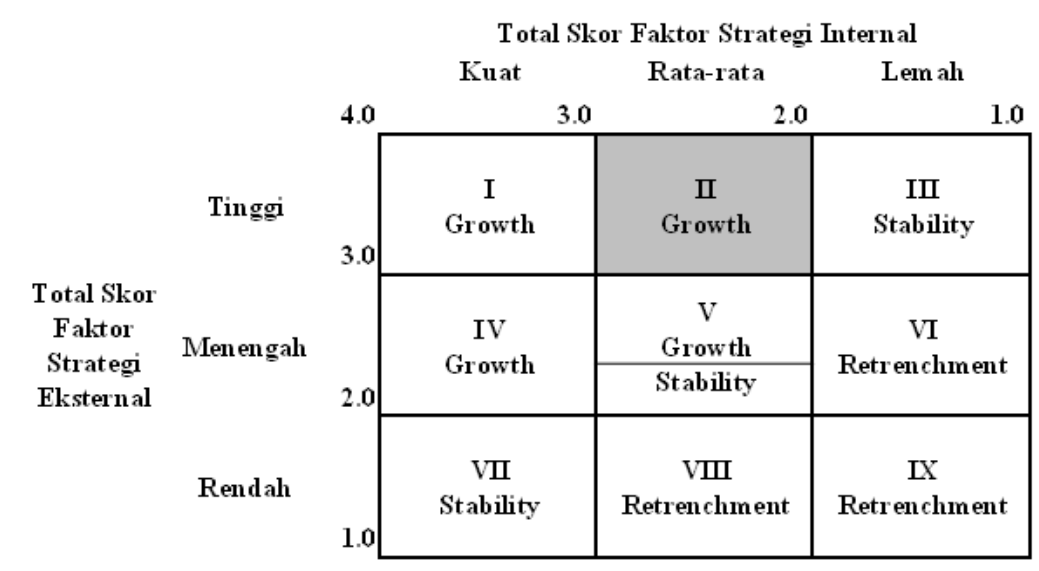

$\begin{array}{ll}\text { Keterangan: } & \\ \text { Sel I, II, IV } & \text { : Pertumbuhan dan Membangun } \\ \text { Sel III, V, VII } & \text { : Pertahankan dan Pelihara } \\ \text { Sel VI, VIII, IX } & \text { : Panen atau Divestasi }\end{array}$

Gambar 3 Matrik Internal Eksternal 
Tabel 3 Matriks Profil Kompetitif (CPM)

\begin{tabular}{|c|c|c|c|c|c|c|c|}
\hline \multirow[t]{2}{*}{ Faktor Penentu Keberhasilan } & \multirow[t]{2}{*}{ Bobot } & \multicolumn{2}{|c|}{$\begin{array}{c}\text { PT. Princess Sound } \\
\text { System }\end{array}$} & \multicolumn{2}{|c|}{ PT. Harry Kiss } & \multicolumn{2}{|c|}{ PT. Sumber Ria } \\
\hline & & Peringkat & Nilai & Peringkat & Nilai & Peringkat & Nilai \\
\hline $\begin{array}{l}\text { Kelengkapan dan kualitas } \\
\text { produk }\end{array}$ & 0,1 & 4 & 0,4 & 4 & 0,4 & 4 & 0,4 \\
\hline Harga yang bersaing & 0,05 & 2 & 0,1 & 2 & 0,1 & 3 & 0,15 \\
\hline Promosi & 0,05 & 1 & 0,05 & 2 & 0,1 & 1 & 0,05 \\
\hline Pelayanan Pelanggan & 0,2 & 4 & 0,8 & 4 & 0,8 & 3 & 0,6 \\
\hline Tingkat penyewaan & 0,15 & 3 & 0,45 & 4 & 0,6 & 3 & 0,45 \\
\hline Pangsa pasar & 0,2 & 3 & 0,6 & 4 & 0,8 & 3 & 0,6 \\
\hline Kesetiaan Pelanggan & 0,15 & 3 & 0,45 & 3 & 0,45 & 3 & 0,45 \\
\hline Kekuatan keuangan & 0,1 & 3 & 0,3 & 4 & 0,4 & 3 & 0,3 \\
\hline Total & 1,0 & & 3,15 & & 3,65 & & 3,0 \\
\hline
\end{tabular}

Matriks grand strategy digunakan untuk merumuskan alternatif strategi, yaitu dengan cara memposisikan organisasi atau perusahaan kedalam salah satu dari empat kuadran yang ada. Matriks ini didasarkan pada dua dimensi evaluatif yaitu posisi kompetitif dan pertumbuhan pasar. Nilai kompetitif sebesar 3.15 (dari matriks profil kompetitif) yang diperoleh perusahaan berada dibawah pesaingnya, ini menjelaskan bahwa perusahaan tersebut memiliki posisi kompetitif yang lemah. Sedangkan pertumbuhan pasar untuk industri ini adalah tinggi. Berdasarkan kedua faktor evaluatif tersebut perusahaan diposisikan kedalam kuadaran II, seperti pada Gambar 4 berikut.

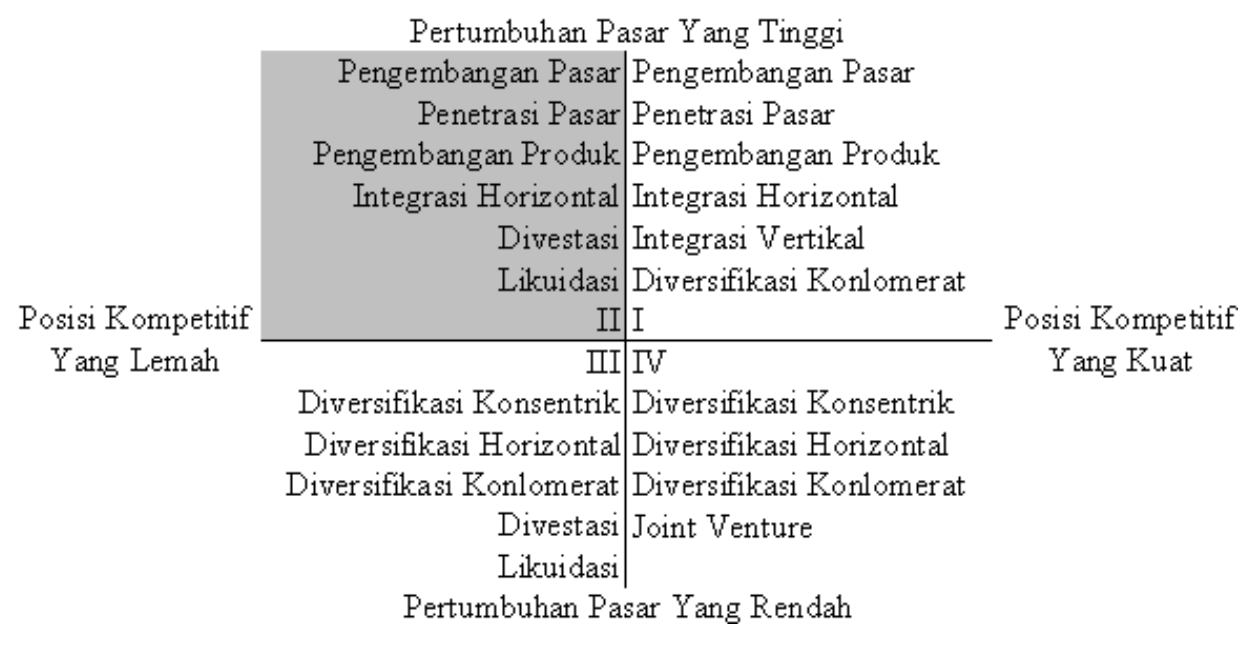

Gambar 4 Matrik Grand Strategy

Dengan menggunakan matriks QSPM maka dapat dipilih salah satu strategi yang dianggap paling sesuai dengan kebutuhan PT Princess Sound System. 
Tabel 3 Matriks QSPM

\begin{tabular}{|c|c|c|c|c|c|c|c|}
\hline \multirow[t]{2}{*}{ Faktor Kunci } & \multirow[t]{2}{*}{ Bobot } & \multicolumn{2}{|c|}{$\begin{array}{l}\text { Penetrasi } \\
\text { Pasar }\end{array}$} & \multicolumn{2}{|c|}{$\begin{array}{c}\text { Pengembangan } \\
\text { pasar }\end{array}$} & \multicolumn{2}{|c|}{$\begin{array}{c}\text { Integrasi } \\
\text { horizontal }\end{array}$} \\
\hline & & AS & TAS & AS & TAS & AS & TAS \\
\hline \multicolumn{8}{|l|}{ Peluang } \\
\hline $\begin{array}{l}\text { Peningkatan } \\
\text { pengguna internet di } \\
\text { Indonesia }\end{array}$ & 0,15 & 4 & 0,6 & 4 & 0,6 & - & - \\
\hline $\begin{array}{lll}\begin{array}{l}\text { Peluang } \\
\text { banyak }\end{array} & \text { yasar } & \text { masih } \\
\text { terjangkau } & \text { belum }\end{array}$ & 0,2 & 1 & 0,2 & 4 & 0,8 & 3 & 0,6 \\
\hline $\begin{array}{l}\text { Teknologi membantu } \\
\text { perusahaan dalam usaha } \\
\text { pemasaran }\end{array}$ & 0,1 & 3 & 0,3 & 3 & 0,3 & 3 & 0,3 \\
\hline $\begin{array}{l}\text { Adanya tren pemasaran } \\
\text { melalui internet }\end{array}$ & 0,2 & 4 & 0,8 & 4 & 0,8 & 4 & 0,8 \\
\hline \multicolumn{8}{|c|}{ Ancaman } \\
\hline $\begin{array}{l}\text { Persaingan usaha } \\
\text { semakin banyak }\end{array}$ & 0,2 & 3 & 0,6 & 4 & 0,8 & 4 & 0,8 \\
\hline $\begin{array}{l}\text { Munculnya pendatang baru } \\
\text { yang potensial }\end{array}$ & 0,15 & 4 & 0,6 & 4 & 0,6 & 2 & 0,3 \\
\hline \multicolumn{8}{|c|}{$\begin{array}{l}1,0 \\
\text { Kekuatan }\end{array}$} \\
\hline $\begin{array}{l}\text { Menawarkan produk } \\
\text { dengan kualitas yang baik }\end{array}$ & 0,15 & 4 & 0,6 & 4 & 0,6 & - & - \\
\hline $\begin{array}{l}\text { Pelayanan merupakan } \\
\text { prioritas perusahaan untuk } \\
\text { memberikan kepuasan bagi } \\
\text { konsumen }\end{array}$ & 0,1 & 4 & 0,4 & 3 & 0,3 & 3 & 0,3 \\
\hline Decision maker & 0,15 & 4 & 0,6 & 4 & 0,6 & - & - \\
\hline $\begin{array}{l}\text { Memiliki } \quad \text { hubungan } \\
\text { kerjasama dengan banyak } \\
\text { pihak }\end{array}$ & 0,15 & 3 & 0,45 & 3 & 0,45 & 4 & 0,6 \\
\hline \multicolumn{8}{|c|}{ Kelemahan } \\
\hline $\begin{array}{l}\text { Brand image yang belum } \\
\text { terkenal }\end{array}$ & 0,05 & 2 & 0,1 & 4 & 0,2 & 3 & 0,15 \\
\hline $\begin{array}{l}\text { Proses pemasaran masih } \\
\text { mengandalkan word of } \\
\text { mouth }\end{array}$ & 0,15 & 2 & 0,3 & 4 & 0,6 & 2 & 0,3 \\
\hline $\begin{array}{l}\text { Tidak memanfaatkan } \\
\text { teknologi informasi secara } \\
\text { maksimal }\end{array}$ & 0,15 & 3 & 0,45 & 3 & 0,45 & 4 & 0,6 \\
\hline $\begin{array}{l}\text { Daerah pemasaran kurang } \\
\text { luas }\end{array}$ & 0,1 & 2 & 0,2 & 4 & 0,4 & 3 & 0,3 \\
\hline \multicolumn{8}{|l|}{ Now } \\
\hline
\end{tabular}

Dari analisis matriks QSPM di atas, hasil yang diperoleh yaitu strategi penetrasi pasar dengan total nilai daya tarik yaitu 6,2, strategi pengembangan pasar dengan total nilai daya tarik sebesar 7,5, dan stategi integrasi horisontal dengan total nilai daya tarik sebesar 5,05. Total nilai daya tarik pada strategi pengembangan pasar yang paling menarik bagi pengembangan PT. Princess Sound System. Strategi yang dapat dilakukan adalah memasarkan produk dengan area pemasaran yang lebih luas untuk menarik pelanggan baru dengan cara menggunakan internet sebagai media promosi. 


\section{Strategi Perencanaan E-Marketing}

Proses bisnis pemasaran yang sedang berjalan seperti pada Gambar 5.

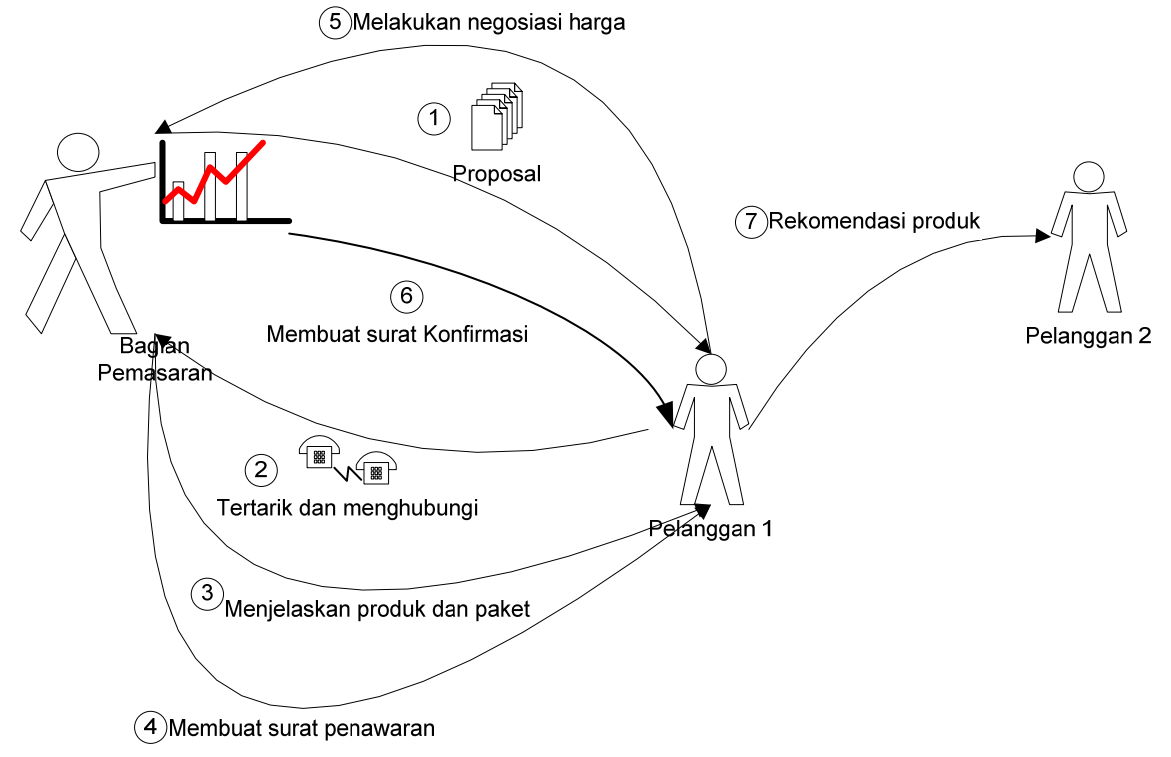

Gambar 5 Proses Pemasaran yang Sedang Berjalan

Pada proses pemasaran, perusahaan melakukan: (1) dengan mengajukan proposal kerja sama dengan beberapa perusahaan seperti event organizer, stasiun televisi, mall, production house, bridal, property dan lainnya. (2) Kemudian apabila perusahaan tersebut tertarik, dapat langsung menghubungi bagian pemasaran PT. Princess Sound System. (3) Setelah itu bagian pemasaran akan menjelaskan produk atau paket yang tersedia secara detail sesuai dengan kebutuhan pelanggan dan (4) membuat surat penawaran. (5) Apabila pelanggan berminat, akan dilakukan negosiasi harga antara dua pihak, (6) kemudian bagian pemasaran akan membuat surat konfirmasi yang akan diberikan kepada pelanggan. (7) Pelanggan juga dapat merekomendasikan perusahaan kepada temannya, dimana merupakan salah satu bentuk pemasaran.

Berdasarkan Market Opportunity Analysis (MOA) didapat beberapa masalah, yaitu:

\section{Mengidentifikasi Kebutuhan Pelanggan yang Belum Terpenuhi}

Untuk mengidentifikasi kebutuhan pelanggan yang belum terpenuhi, dapat terlihat dari hasil penyebaran kuesioner dan dapat ditarik simpulan bahwa pelanggan kurang mendapat penawaran dari perusahaan dan sulit mengetahui produk dan ketersediaan produk. Kurangnya promosi yang dilakukan PT Princess Sound System menyebabkan pelanggan kurang mendapatkan penawaran produk, sehingga pelanggan tidak mengetahui paket dan promosi yang sedang ditawarkan. Dari hasil kuesioner menunjukkan bahwa 90,48\% dari responden menjawab tidak pernah mendapatkan promosi dari PT. Princess Sound System.

Pelanggan sulit mengetahui ketersediaan produk yang ingin disewa, sehingga harus menghubungi pihak pemasaran terlebih dahulu dan harus menunggu konfirmasi dari pihak pemasaran. Hasil kuesioner menunjukkan bahwa sebanyak 71,43\% dari responden menjawab bahwa tidak mudah untuk memperoleh informasi tentang produk dan ketersediaan produk yang ingin disewa. Apabila terdapat katalog produk yang dapat selalu update, maka pelanggan dapat melihat langsung dari katalog tersebut informasi tentang produk yang ingin disewa. 


\section{Mengidentifikasi Pelanggan Tertentu yang akan Dituju oleh Perusahaan}

Berdasarkan analisis dari proses bisnis dalam perusahaan, mencakup beberapa segmentasi pasar: geografi, demografi, dan psikografi. Secara geografis, segmen pasar PT. Princess Sound System sebagian besar berada di wilayah Jabodetabek, tetapi perusahaan juga melayani penyewaan di luar Pulau Jawa. Secara demografis, segmen pasar PT. Princess Sound System dibagi berdasarkan bidang pekerjaan seperti, event organizer, bridal atau modeling, production house, television. Berdasarkan pendapatan dibagi menjadi konsumen berpenghasilan kecil, menengah, dan besar. Sementara itu, secara firmografis, segmen pasar PT. Princess Sound System dibagi menjadi pelanggan individual, dan organisasi (perusahaan). Pelanggan individual berarti pelanggan ini melakukan penyewaan atas kepentingan pribadi atau individu, sedangkan organisasi melakukan penyewaan atas kepentingan perusahaan dalam penyelenggaraan event- event.

\section{Menilai Keuntungan yang Berkaitan dengan Kompetisi}

Dalam intensitas persaingan, perusahaan mempunyai pesaing langsung dan tidak langsung, yakni: (1) direct competitor (pesaing langsung): Harry Kiss dan Sumber Ria, kedua perusahaan ini merupakan direct competitor karena bergerak di bidang yang sama, dan memiliki target pelanggan yang sama; (2) indirect competitor (pesaing tidak langsung): Platinum Audio dan Deltamusik.com, dikelompokkan dalam indirect competitor karena secara tidak langsung menawarkan produk yang memiliki fungsi yang sama. Setelah itu dilakukan pemetaan kompetitor ke dalam segmentasi tertentu, seperti pada Tabel 4.

Tabel 4 Customer Mapping

\begin{tabular}{|c|c|c|c|c|c|}
\hline $\begin{array}{c}\text { Dimensi } \\
\text { Perbandingan }\end{array}$ & $\begin{array}{l}\text { PT. Princess } \\
\text { Sound System }\end{array}$ & Harry Kiss & Sumber Ria & $\begin{array}{l}\text { Platinum } \\
\text { Audio }\end{array}$ & $\begin{array}{c}\text { Delta } \\
\text { musik.com }\end{array}$ \\
\hline Pengenalan Mer & & & & & \\
\hline Promosi & & & & & \\
\hline Teknologi & & & & & \\
\hline
\end{tabular}

Keterangan :

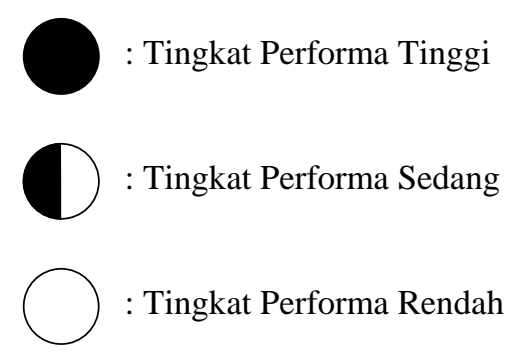

\section{Menilai Sumber Daya Perusahaan untuk Memberikan Penawaran}

Adapun keunggulan yang dimiliki oleh perusahaan untuk memaksimalkan penawaran bagi pelanggan, yakni: customer-facing resources, internal resources, dan upstream resources. Dalam customer-facing resources, PT Princess Sound System memiliki beberapa kantor cabang yang berada di daerah Tanjung Duren, Kedoya dan Meruya. Kantor-kantor cabang ini memudahkan perusahaan 
untuk mendistribusikan produk dan mempercepat pengiriman apabila lokasi penyewaan berada di daerah tersebut. PT Princess Sound System juga memiliki brand name yang sudah cukup dikenal di kalangan tertentu, karena perusahaan ini telah berdiri selama 28 tahun, dan selalu memberikan layanan terbaik dengan menyediakan produk yang berkualitas. PT Princess Sound System memiliki bagian pemasaran yang ahli dan berpengalaman, serta selalu mengedepankan pelayanan bagi pelanggan, sehingga meningkatkan loyalitas dan kepuasan pelanggan.

Dalam internal resource, PT Princess Sound System memiliki 78 karyawan yang terdiri dari bagian pemasaran, keuangan, operasional, dan gudang. Karyawan memiliki pengalaman dan keahlian pada bidang masing-masing, terutama pada bagian pemasaran dan keuangan yang memiliki kemampuan dalam menggunakan teknologi komputerisasi dan internet sehingga tidak akan mengalami kesulitan dalam menerapkan pemasaran secara online. Sementara, dalam upstream resource, PT Princess Sound System bekerja sama dengan berbagai perusahaan yang menjual alat-alat sound system, lighting dan multimedia, seperti PT. Cantika, PT. Batavia, PT. Ghosen, PT. Trisha.

\section{Menilai Kesiapan Pasar akan Teknologi}

Teknologi yang digunakan dalam mendukung proses bisnisnya, adalah spesifikasi komputer yaitu: (1) motherboard: Biostar Tforce; (2) processor: E7500 Box (3M Cache, $2.93 \mathrm{GHz}$ ); (3) hard drive PC: WDC 500Gb SATA-II 32Mb; (4) memory RAM DDR 2: TEAM 1GB*2 PC2 6400 DDR2 800MHz; (5) VGA: Zotac 9500GT 512Mb 128Bit DDR2; (6) monitor: BenQ 18.5 Inch; (7) casing: Simbadda Sim Cool; (8) keyboard dan mouse: Logitech Black PS/2; (9) printer: Canon MP 145.

Untuk mendukung e-marketing yang akan diterapkan oleh perusahaan, telah dipersiapkan jaringan internet dengan kecepatan koneksi yang mampu mendukung operasi bisnis yang dilakukan melalui website. Akses internet yang akan digunakan oleh PT. Princess Sound System adalah SmartTelecom paket Platinum yang memiliki kecepatan download sampai dengan 3,1 Mbps dan kecepatan upload sampai dengan 384 Kbps dengan harga per bulannya adalah 140.000 rupiah.

\section{Menentukan Peluang Secara Konkret}

Penentuan peluang secara konkret, yaitu: (1) value proposition: banyaknya pelanggan yang membutuhkan jasa penyewaan sound system menjadi peluang bagi perusahaan; (2) customer benefits: perusahaan memiliki sound system yang lengkap dengan kualitas yang baik, sehingga dapat memenuhi keinginan pelanggan; (3) critical resources: perusahaan memiliki produk dan layanan yang berkualitas; (4) reasons to believe: dengan reputasi perusahaan yang baik, pelanggan akan lebih percaya untuk bertransaksi; (5) resource sourcing: perusahaan memiliki sumber daya manusia yang ahli dan berpengalaman di bidangnya; (6) how to monetize: bertambahnya jumlah pengguna internet meningkatkan peluang perusahaan untuk menggunakan website dalam promosi dan penyewaan online; (7) opportunity magnitude: terdapat peluang besar bagi perusahaan untuk mendapatkan pelanggan lebih banyak.

\section{Menilai Peluang Daya Tarik bagi Pelanggan}

Setelah dilakukan analisis, berikut ini adalah 8 faktor yang mempengaruhi penilaian peluang perusahaan untuk berbisnis secara online, yaitu:

\section{Competitive Vulnerability}

PT Princess Sound System melihat adanya peluang untuk memasarkan produk melalui website dengan tujuan meningkatkan popularitas perusahaan. Pesaing-pesaing perusahaan ini masih belum mengembangkan pemasaran secara online. Oleh sebab itu, faktor ini menjadi faktor positif bagi PT Princess Sound System. 


\section{Technical Vulnerability}

E-marketing yang akan dikembangkan merupakan salah satu strategi pemasaran pendukung yang melengkapi sistem pemasaran yang ada saat ini. Saat ini perusahaan memiliki komputer dengan spesifikasi hardware dan software yang memadai serta telah dipersiapkan jaringan internet yang dapat mendukung penerapan e-marketing. Selain itu, perusahaan ini memiliki karyawan-karyawan yang mampu mengoperasikan komputer dan internet dengan baik. Jadi dapat disimpulkan bahwa penerapan e-marketing merupakan faktor positif.

\section{Magnitude of Unmet Need}

Faktor magnitude of unmet need dinilai positif karena dengan adanya penerapan aplikasi $e$ marketing akan memudahkan perusahaan untuk mengatasi kebutuhan pelanggan yang belum terpenuhi. Aplikasi e-marketing ini dapat membantu pelanggan dalam mendapatkan informasi produk yang lengkap, akses informasi yang mudah, dan proses booking yang lebih cepat.

\section{Interaction between Segments}

Dalam hal interaksi antar segmen, termasuk dalam faktor positif. Dikarenakan interaksi dalam segmentasi konsumen cukup baik dimana sering kali terjadi transaksi dari konsumen baru yang ternyata mendapat referensi dari keluarga atau teman yang pernah menggunakan jasa penyewaan sound system PT. Princess Sound System. Jadi dengan pemanfaatan e-marketing tersebut dapat menjadi wadah interaksi antara konsumen dengan masyarakat umum untuk menggunakan produk perusahaan.

\section{Likely Rate of Growth}

Tingkat pertumbuhan PT Princess Sound System dinilai positif karena pertumbuhan yang dialami perusahaan ini dari sejak berdiri hingga saat ini mengalami peningkatan. Dengan adanya strategi marketing online, tingkat pertumbuhan perusahaan akan makin berkembang, karena jangkauan pasar akan semakin luas.

\section{Technology Vulnerability}

Teknologi yang digunakan oleh PT Princess Sound System termasuk standar karena hanya menggunakan komputer, mesin fax, telepon, scanner, dan mesin fotocopy. Maka dapat dikategorikan sebagai faktor netral.

\section{Market Size}

PT Princess Sound System memiliki market size yang belum begitu luas karena kurangnya promosi yang dilakukan. Dengan menerapkan e-marketing akan mendukung bertambahnya ukuran pasar perusahaan yang sebagian besar pelanggannya hanya berasal dari Jakarta dan sekitarnya. Dengan demikian, faktor ini dapat dikategorikan sebagai faktor netral.

\section{Level of Profitability}

Tingkat keuntungan PT Princess Sound System yang terus meningkat dari tahun ke tahun merupakan faktor positif untuk mengembangkan e-marketing yang diharapkan dapat memperbesar tingkat keuntungan perusahaan dengan adanya peningkatan transaksi yang berlangsung. 


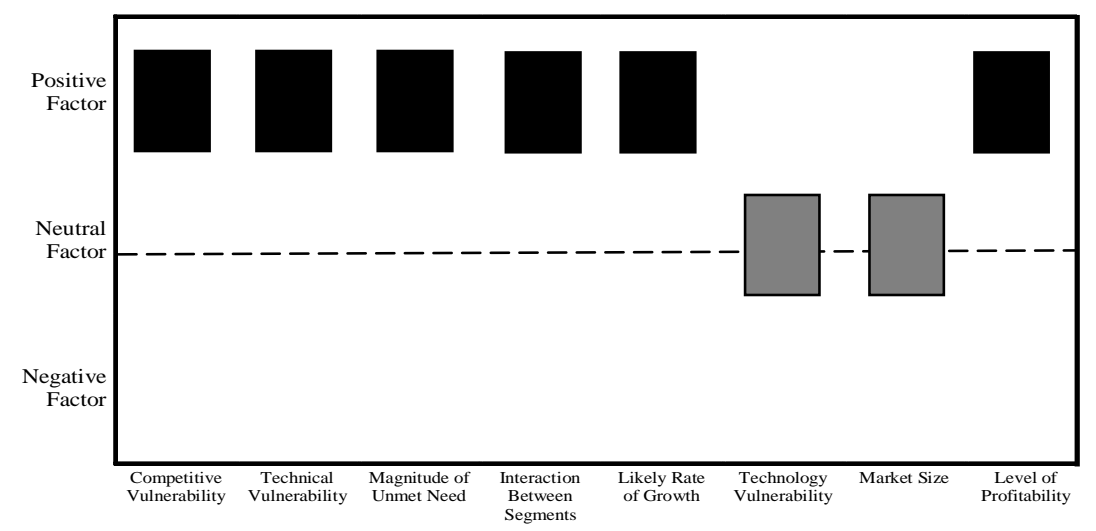

Gambar 6 PT Princess Sound System Opportunity’s Attractiveness

Kesimpulan dari analisa tahap ini adalah bahwa PT Princess Sound System bisa bergerak ke arah online karena faktor positif yang dimiliki lebih banyak daripada faktor negatif dan faktor netral. Karena itu, keputusan yang dihasilkan adalah PT Princess Sound System bisa menggunakan website sebagai sarana pemasarannya.

Strategi perencanaan yang akan dibuat adalah memakai sistem pemasaran online. Berikut ini meliputi strategi perencanaan, yaitu diferensiasi dan posisi.

\section{Diferensiasi}

Terdapat enam strategi diferensiasi yang dapat digunakan untuk bisnis online, yaitu:

\section{Site Environment/Atmospherics}

Untuk menciptakan suasana seperti dalam toko fisik, pengguna diberikan beberapa suasana dalam website yang menyerupai toko fisik, yaitu: (1) navigasi website yang jelas sehingga mudah digunakan; (2) terdapat katalog produk yang memudahkan pengguna dalam mencari informasi dan ketersediaan produk; (3) terdapat daftar acara-acara yang pernah diadakan PT. Princess Sound System dalam waktu dekat, beserta informasi lengkapnya, sehingga pengguna dapat mengetahui berbagai acara yang sudah pernah dan akan ditangani.

\section{Build Trust}

Kepercayaan merupakan masalah kunci dalam internet, karena informasi pelanggan merupakan privasi. Maka, website menggunakan proses autentifikasi pengguna dengan username dan password.

\section{Efficient and Timely Order Processing}

Motivasi terkuat bagi pelanggan untuk melakukan transaksi melalui website adalah kemudahan dalam pemesanan. Maka website PT Princess Sound System menyediakan kemudahan seperti dapat melakukan booking melalui website dan menentukan jadwal pertemuan negosiasi dengan pihak perusahaan.

\section{Pricing}

Untuk dapat menarik pelanggan, harga sebagai metode diferensiasi harus berada di bawah pengawasan, maka diberikan diskon khusus bagi pelanggan yang melakukan pemesanan melalui website. 


\section{Customer Relationship Management (CRM)}

Dalam menjaga hubungan dengan pelanggan, perusahaan menyimpan data pelanggan yang telah melakukan penyewaan melalui website, sehingga pelanggan dapat lebih mudah dalam melakukan penyewaan kembali. Selain itu juga terdapat layanan dimana perusahaan dan pelanggan dapat saling berkomunikasi.

\section{Invite User-Generated Content}

Dalam website PT Princess Sound System disediakan beberapa layanan yang memungkinkan pelanggan mereferensikan pada teman, layanan yang menghubungkan dengan situs jejaring sosial dan juga layanan dimana pelanggan dapat menuliskan kesan dan pesan untuk perusahaan.

\section{Posisi}

Strategi posisi yang digunakan adalah technology positioning, di mana PT Princess Sound System menempatkan website-nya sebagai situs yang menyediakan fasilitas booking online dan dilengkapi dengan kemudahan untuk menentukan jadwal negosiasi sesuai keinginan pelanggan.

\section{Tujuan}

Visi, misi, sasaran perusahaan harus didefinisikan dengan jelas. Tujuan dalam rencana $e$ marketing yang ingin dicapai adalah: meningkatkan penyewaan; mengurangi biaya operasional dan komunikasi; membangun brand awareness perusahaan; meningkatkan jumlah pelanggan; meningkatkan loyalitas pelanggan; meningkatkan kepuasan pelanggan; membangun inovasi dalam layanan online; mengoptimalkan respon administrator untuk setiap pertanyaan yang diajukan melalui situs.

\section{Strategi E-Marketing}

\section{Product Strategies}

Dari segi produk, PT Princess Sound System memiliki berbagai macam produk seperti sound system (speaker, rigging, band equipment \& monitor system, broadcast system, mic), lighting system (stage lighting, moving head \& scanner, effect, laser), dan multimedia system (screen, lcd projector, camera shooting, genzet). PT Princess Sound System menyediakan fitur untuk memudahkan pencarian produk, memberikan informasi detail untuk setiap produk, memberikan rekomendasi produk berdasarkan kebutuhan acara, memberikan layanan booking secara online dan memungkinkan pelanggan untuk men-download katalog produk.

\section{Pricing Strategies}

Dari segi harga, PT Princess Sound System akan menerapkan strategi harga yang dinamis yaitu penetapan harga berdasarkan segmen, penetapan harga melalui negosiasi dan pemberian diskon. Dengan penetapan harga berdasarkan segmen, perusahaan akan mengenakan biaya trasportasi yang berbeda-beda sesuai dengan lokasi pengiriman. Sedangkan dengan penetapan harga melalui negosiasi, pelanggan dapat melakukan negosiasi harga dengan perusahaan untuk mendapatkan kesepakatan harga yang menguntungkan bagi kedua belah pihak. Selain itu, strategi harga dengan pemberian diskon yang diberikan kepada pelanggan baru, pelanggan yang telah melakukan transaksi di atas 10 kali, dan pelanggan yang mereferensikan perusahaan kepada orang lain. 


\section{Place (Distribution) Strategies}

Dalam menyediakan produk untuk disewakan kepada pelanggan, PT Princess Sound System memperoleh produk-produknya langsung dari para distributor. PT Princess Sound System didistribusi oleh PT Cantika, PT Batavia, PT Gosen, dan PT Trisha untuk produk-produk soundsystem dan lighting dengan merek LAX, Antari, Mackie, Avolites, dbx Professional, Allen \& Heath, Ashly.

\section{Promotion (Communication) Strategies}

Bentuk komunikasi yang akan diterapkan perusahaan melalui website-nya yaitu: (1) situs dibuat user-friendly dengan tampilan yang menarik dan navigasi yang jelas serta mudah. Dalam menyebarluaskan penggunaan website ini, perusahaan akan mempromosikan kepada para pelanggan tetap untuk mengunjungi website dan mereferensikan untuk melakukan penyewaan secara online. Para pelanggan tetap yang telah mengunjungi situs dapat mereferensikan situs perusahaan kepada orang lain; (2) PT Princess Sound System menyediakan diskon khusus untuk setiap penyewaan diatas 10 kali melalui website-nya, diskon tambahan pada transaksi pertama secara online bagi setiap pelanggan barunya, dan diskon untuk pelanggan yang mereferensikan perusahaan pada orang lain; (3) perusahaan menyediakan layanan untuk berkomunikasi dengan sesama member dan dengan perusahaan.

\section{Relationship Management Strategies}

Strategi hubungan manajemen terdiri dari: (1) peningkatan jumlah pelanggan, dengan penerapan CRM, perusahaan berusaha menarik pelanggan-pelanggan baru dengan memberikan promosi berupa diskon pada pelanggan yang baru bergabung dan adanya layanan untuk mereferensikan perusahaan; (2) peningkatan penyewaan, dengan penerapan CRM, perusahaan berusaha meningkatkan tingkat penyewaan dengan memberikan promosi melalui diskon-diskon, strategi negosiasi dimana pelanggan dapat melakukan negosiasi harga dengan pihak perusahaan untuk mendapatkan harga yang sesuai dengan budget dan keinginan pelanggan, dan memberikan rekomendasi paket sehingga pelanggan dapat lebih mudah menentukan paket sesuai kebutuhan dari acara yang akan diadakan; (3) peningkatan kesetiaan pelanggan lama, dengan penerapan CRM, perusahaan berusaha meningkatkan kesetiaan pelanggan dengan menyediakan layanan komunikasi yang interaktif bagi pelanggan dan promosi berupa diskon-diskon bagi pelanggan tetap.

\section{Rencana Pelaksanaan}

Teknologi internet telah menyebabkan perubahan dalam hal cara pelanggan berinterakasi dengan perusahaan. Saat ini interaksi antara pelanggan dengan perusahaan yang pada awalnya dilakukan secara langsung atau melalui tatap muka mulai digantikan dengan interaksi melalui layar komputer. Ketika terjadi pergeseran dalam interaksi dengan mediasi manusia ke arah mediasi teknologi, maka sangat penting untuk melakukan pertimbangan-pertimbangan dalam hal mendesain interface yang dapat mempengaruhi pengalaman pelanggan.

Terdapat beberapa aturan desain untuk menciptakan interface pelanggan bermediasi teknologi sebuah website sehingga menjadi sukses, dengan berfokus pada interface web yang merupakan bagian kritikal dari program pemasaran. 
Tabel 5 Hubungan Strategi dengan Fitur-fitur e-Marketing

\begin{tabular}{|c|c|c|}
\hline Tujuan & Strategi & Fitur \\
\hline Meningkatkan pendapatan & $\begin{array}{ll}\text { - } & \text { Strategi pengembangan pasar } \\
\text { - } & \text { Strategi penetrasi pasar } \\
\text { - } & \text { Strategi CRM : } \\
\text { - Promosi diskon } \\
\text { - Negosiasi harga } \\
\text { - Rekomendasi paket berdasarkan } \\
\quad \text { kebutuhan pelanggan }\end{array}$ & $\begin{array}{ll}\text { - } & \text { Booking produk atau paket } \\
\text { - } & \text { Katalog produk } \\
\text { - } & \text { Rekomendasi paket } \\
\text { - } & \text { Kalender negosiasi } \\
\text { - } & \text { Welcome Price } \\
\text { - } & \text { Ten of } 10 \\
\text { - } & \text { Tell a Friend Bonus }\end{array}$ \\
\hline $\begin{array}{l}\text { Mengurangi biaya operasional } \\
\text { dan komunikasi }\end{array}$ & $\begin{array}{l}\text { Strategi SO : } \\
\text { - mengembangkan pemasaran dengan } \\
\quad \text { merancang web e-marketing }\end{array}$ & Booking produk atau paket \\
\hline Membangun brand awareness & Strategi komunikasi & $\begin{array}{l}\text { Tell a Friend } \\
\text { Komunitas Facebook }\end{array}$ \\
\hline $\begin{array}{l}\text { Meningkatkan jumlah } \\
\text { pelanggan }\end{array}$ & $\begin{array}{l}\text { - } \text { Strategi pengembangan pasar } \\
\text { - } \quad \text { Strategi SO : Memperluas daerah } \\
\text { pemasaran untuk meningkatkan jumlah } \\
\text { pelanggan } \\
\text { - } \quad \text { Strategi CRM : } \\
\text { - Promosi diskon pada pelanggan } \\
\quad \text { yang baru bergabung } \\
\text { - Layanan untuk mereferensikan } \\
\text { perusahaan }\end{array}$ & $\begin{array}{ll}- & \text { Katalog produk } \\
- & \text { Cari produk } \\
- & \text { Komentar produk } \\
\text { - } & \text { Rekomendasi paket } \\
\text { - } & \text { Booking produk atau paket } \\
- & \text { Download katalog produk } \\
- & \text { Kalender Negosiasi } \\
- & \text { Welcome Price } \\
- & \text { Ten of } 10 \\
- & \text { Tell a Friend Bonus } \\
- & \text { Testimonial } \\
- & \text { Tell a Friend }\end{array}$ \\
\hline $\begin{array}{l}\text { Meningkatkan kesetiaan } \\
\text { pelanggan }\end{array}$ & $\begin{array}{l}\text { - } \quad \text { Strategi CRM : } \\
\text { - Layanan komunikasi yang interaktif } \\
\quad \text { bagi pelanggan } \\
\text { - Promosi diskon bagi pelanggan tetap } \\
\text { - } \quad \begin{array}{l}\text { Strategi SO : mempererat kerja sama } \\
\text { dengan pelanggan tetap }\end{array}\end{array}$ & $\begin{array}{ll}- & \text { Forum } \\
- & \text { Yahoo! Messenger } \\
- & \text { Chatbox } \\
- & \text { Tell a Friend } \\
\text { - } & \text { Welcome } \text { Price } \\
- & \text { Ten of } 10 \\
\text { - } & \text { Tell a Friend Bonus }\end{array}$ \\
\hline $\begin{array}{l}\text { Meningkatkan kepuasan } \\
\text { pelanggan }\end{array}$ & $\begin{array}{l}\text { - Strategi SO : memelihara kualitas dan } \\
\text { mutu pelayanan } \\
\text { - } \quad \text { Strategi harga }\end{array}$ & $\begin{array}{ll}- & \text { Kalender negosiasi } \\
- & \text { Forum } \\
\text { - } & \text { Yahoo! Messenger } \\
- & \text { Chatbox } \\
\text { - } & \text { Tell a Friend }\end{array}$ \\
\hline $\begin{array}{l}\text { Membangun inovasi dalam } \\
\text { layanan online }\end{array}$ & $\begin{array}{ll}\text { - } & \text { Strategi produk } \\
\text { - } & \text { Strategi distribusi } \\
\text { - } & \text { Strategi integrasi horisontal }\end{array}$ & $\begin{array}{ll}\text { - } & \text { Katalog produk } \\
\text { - } & \text { Cari produk } \\
\text { - } & \text { Komentar produk } \\
\text { - } & \text { Rekomendasi paket } \\
\text { - } & \text { Booking produk atau paket } \\
\text { - } & \text { Download katalog produk } \\
\text { - } & \text { Search engine Google } \\
\text { - } & \text { Link ke perusahaan distributor }\end{array}$ \\
\hline $\begin{array}{l}\text { Mengoptimalkan respon } \\
\text { administrator untuk setiap } \\
\text { pertanyaan yang diajukan } \\
\text { melalui web }\end{array}$ & $\begin{array}{l}\text { Strategi CRM : layanan komunikasi yang } \\
\text { interaktif bagi pelanggan }\end{array}$ & $\begin{array}{ll}- & \text { Forum } \\
\text { - } & \text { Yahoo! Messenger } \\
- & \text { Chatbox }\end{array}$ \\
\hline
\end{tabular}

Dalam merancang interface pelanggan dalam e-marketing, perusahaan menggunakan pedoman tujuh elemen (7C) perancangan interface pelanggan yang meliputi (pada Tabel 6). 
Tabel 6 Tujuh Elemen Perancangan Interface

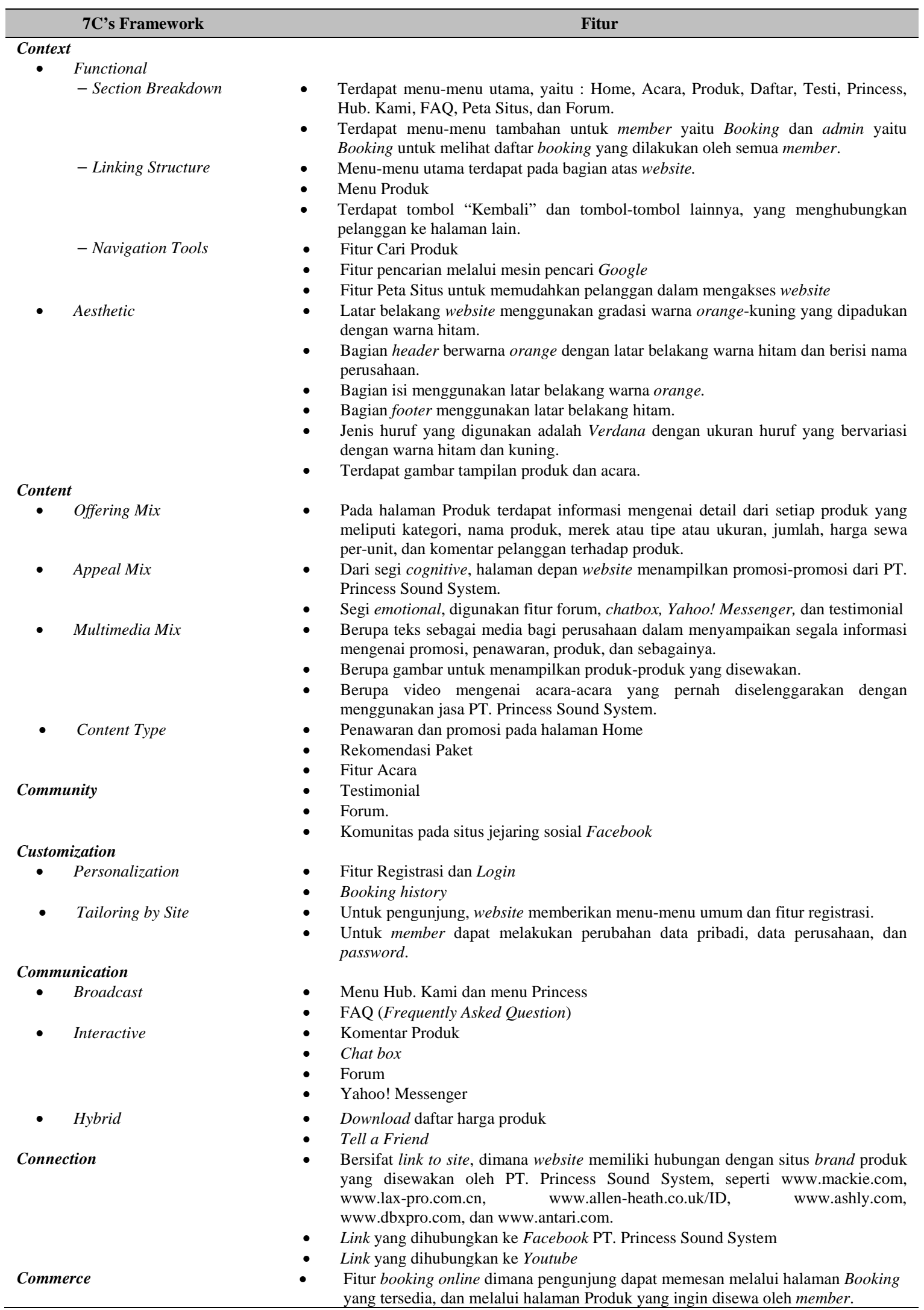




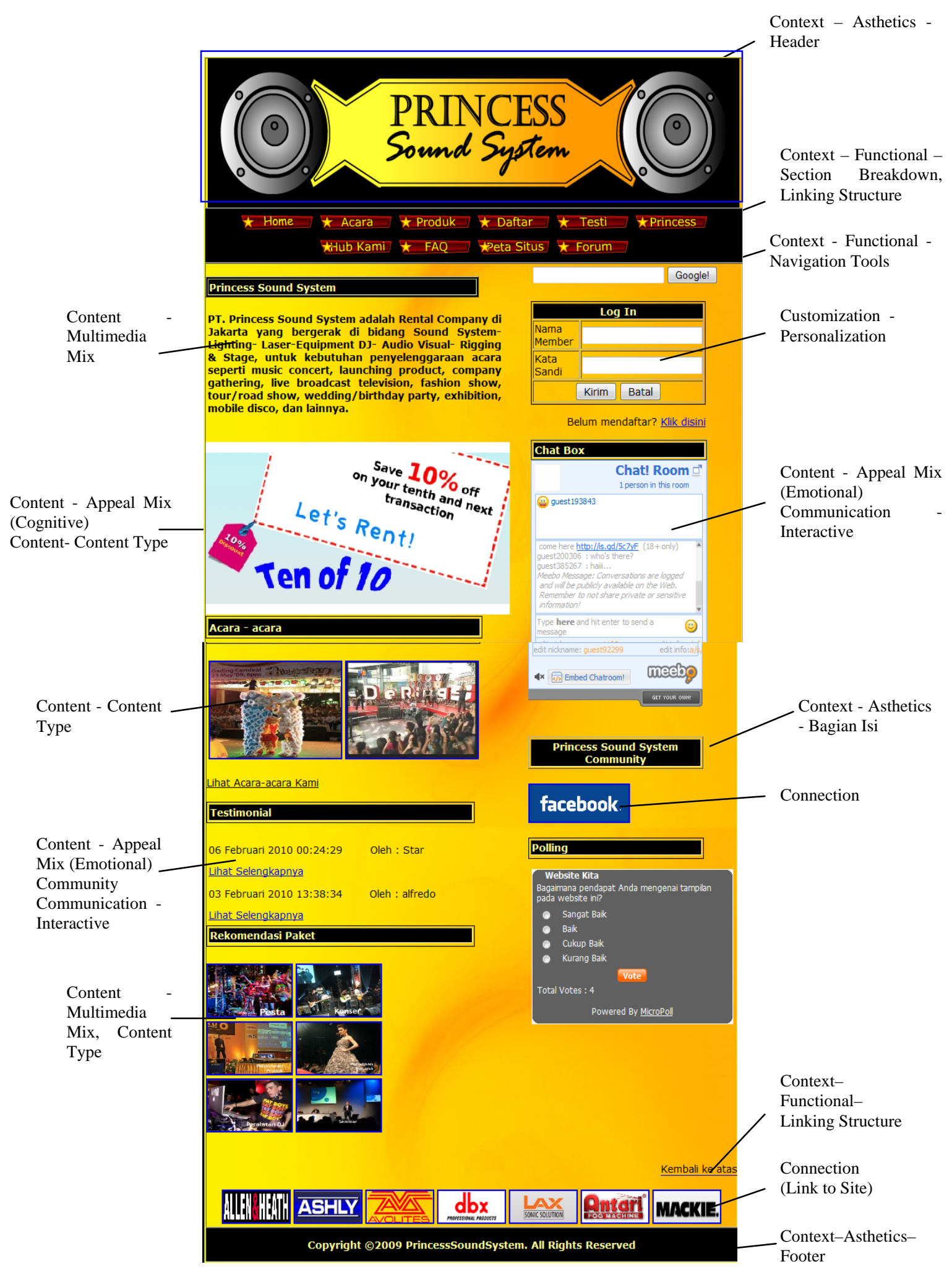

Gambar 7 Contoh Interface 


\section{Anggaran}

Tabel 7 Pendapatan Tahun 2004 - 2009

\begin{tabular}{ccccc}
\hline Tahun & Pendapatan $(\mathbf{y})$ & $\mathbf{x}$ & $\mathbf{x} \cdot \mathbf{y}$ & $\mathbf{x}^{2}$ \\
\hline 2004 & 48 & -5 & -240 & 25 \\
2005 & 50 & -3 & -150 & 9 \\
2006 & 51 & -1 & -51 & 1 \\
2007 & 49 & 1 & 49 & 1 \\
2008 & 55 & 3 & 165 & 9 \\
2009 & 61 & 5 & 305 & 25 \\
& $\sum \mathrm{y}=314$ & $\sum \mathrm{x}=0$ & $\sum \mathrm{xy}=78$ & $\sum \mathrm{x}^{2}=70$ \\
\hline
\end{tabular}

$$
\mathbf{y}=\mathbf{a}+\mathbf{b x}
$$

Keterangan : $\mathrm{y}=$ pendapatan $; \mathrm{x}=$ waktu

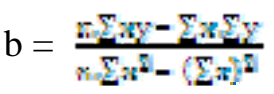

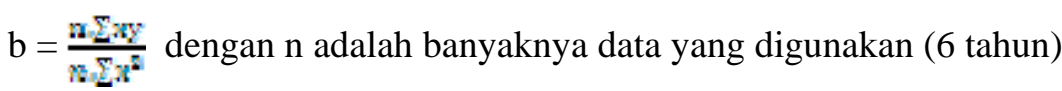

$$
\begin{aligned}
& \mathrm{b}=\frac{678}{6.72}=\frac{468}{420}=1.11 \\
& \mathrm{a}=\bar{y}-b_{\mathrm{n}} \bar{x} \text { dengan } \bar{y}=\frac{\Sigma y}{\mathrm{~m}}=\frac{814}{\epsilon}=52.3 \\
& \bar{x}=\frac{\sum x}{\mathrm{n}}=\frac{0}{6}=0 \\
& \mathrm{a}=52.3 \\
& y=52.3+(1.11 \times 7)=60.07
\end{aligned}
$$

Perkiraan pendapatan pada tahun $2010=60.07$ x 100.000.000 = Rp 6.007.000.000,-

Dengan menggunakan e-marketing, tingkat penyewaan dalam jangka waktu 1 tahun diperkirakan:

- Dari perkiraan optimis, meningkat sebesar 10\%, maka perkiraan pendapatan setelah pengimplementasian e-marketing adalah :

Rp 6.007.000.000 + (10\% x Rp 6.007.000.000) $=\underline{\mathbf{R p ~ 6 . 6 0 7 . 7 0 0 . 0 0 0 , -}}$

- Dari perkiraan pesimis, meningkat sebesar 5\%, maka perkiraan pendapatan setelah pengimplementasian e-marketing adalah :

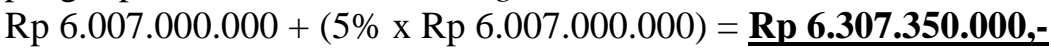

Dengan adanya implementasi website, perusahaan dapat melakukan penghematan biaya, antara lain :

- Penggunaan kertas

Sebelum implementasi :

Biaya kertas HVS $\quad$ : Rp. 2.050.400,-

Kertas fax : Rp. 2.520.000,-

Refill tinta printer
Total $\quad \frac{\text { Rp. 2.556.000,- }+}{\text { Rp. 7.126.400,- }}$ 
Sesudah implementasi :

$\begin{array}{rll}\text { Biaya kertas HVS } & : & \text { Rp. 1.475.300,- } \\ \text { Kertas fax } & : & \text { Rp. 1.738.200,- } \\ \text { Refill tinta printer } & : & \text { Rp. 1.800.000,- + } \\ \text { Total } & : & \text { Rp. 5.013.500,- }\end{array}$

Perusahaan melakukan penghematan sebesar :

Biaya sebelum implementasi - Biaya sesudah implementasi = Rp. 2.112.900,-

Persentase pengehematan biaya penggunaan kertas :

$$
\frac{\text { Rp. 2.112.900,-- }}{\text { Rp. 7.126.400,-- }} \times 100 \%=\mathbf{2 9 . 6 4 \%}
$$

- $\quad$ Biaya telekomunikasi

Sebelum implementasi : : Rp. 10.375.600,-

Sesudah implementasi : $\quad$ Rp. 8.070.000,-

$$
\text { Rp. 2.305.600,- }
$$

Persentase penghematan telekomunikasi sebesar :

$$
\frac{\text { Rp. } 2.305 .600,-}{\text { Rp. } 10.375 .600,-} \text { X 100\% = 22,22\% }
$$

Biaya yang dibutuhkan untuk pengimplementasian website adalah :

- Biaya teknologi

$$
\begin{array}{llll}
\text { Router dan Modem Smart } & : & \text { Rp. } & \text { 2.678.000,- / tahun } \\
\text { Hosting } & : & \text { Rp. } & 300.000,- \text { / tahun } \\
\text { Maintenance web } & : & \text { Rp. } & 750.000,- \text { / } 6 \text { bulan }
\end{array}
$$

- Rancangan situs

Biaya desain web $\quad$ : Rp. 1.000.000,-

- Gaji

Administrator : Rp. 4.000.000,- / bulan

Database Administrator : Rp. 4.500.000,- / bulan

- Pengembangan situs

Pengembangan situs $\quad$ : Rp. 2.000.000,-

Keuntungan tidak nyata adalah: (1) meningkatkan brand awareness sehingga perusahaan dapat lebih dikenal masyarakat. Peningkatan brand awareness juga akan membantu meningkatkan pendapatan perusahaan; (2) meningkatkan hubungan baik antara perusahaan dan pelanggan. Dengan Customer Relationship Management (CRM) yang baik akan membangun kesetiaan pelanggan terhadap perusahaan.

\section{Rencana Evaluasi}

Tahap evaluasi ini adalah tahap terakhir dari pengembangan e-marketing. Tahap evaluasi penting dilakukan untuk mengetahui apakah website yang sudah dibuat sudah memenuhi kriteria teknologi, manfaat dan juga interface atau tampilan terbaik. Serta tahap evaluasi ini dilakukan juga untuk mengetahui tanggapan perusahaan terhadap website yang telah dibuat. 


\section{SIMPULAN}

Dalam mengimplementasikan aplikasi e-marketing, strategi perencanaan yang cocok untuk retail company meliputi: (1) dari hasil analisis situasi, strategi yang tepat untuk diterapkan adalah strategi pengembangan pasar, yaitu memasarkan produk dengan area pemasaran yang lebih luas untuk menarik pelanggan baru melalui internet sebagai media promosi; (2) dari hasil Market Opportunity Analysis (MOA), segmen yang menjadi target utama perusahaan adalah pelanggan individual ataupun perusahaan berskala besar yang berlokasi di daerah Jabodetabek. Strategi differentiation dan positioning yang dilakukan oleh perusahaan adalah menempatkan website-nya sebagai situs yang menyediakan fasilitas booking online dan dilengkapi dengan kemudahan untuk menentukan jadwal negosiasi sesuai keinginan pelanggan; (3) solusi e-marketing yang diterapkan oleh perusahaan baik dalam segi produk, harga, komunikasi atau promosi, dan hubungan dengan pelanggan adalah fiturfitur, antara lain: Booking Online, Kalender Negosiasi, Rekomendasi Paket, Katalog Produk, Cari Produk, Komentar Produk, Download Katalog Produk, Welcome Price, Ten of 10, Tell a Friend Bonus, Testimonial, Tell a Friend, Forum, Chat Box, Yahoo! Messenger, Polling, Registrasi, dan Komunitas di Facebook.

\section{DAFTAR PUSTAKA}

Kotler, P., \& Amstrong, G. (2004). Principles of Marketing (10th ed.). Upper Saddle River, New Jersey: Pearson Education.

Mohammed, R. A., et. al. (2003). Internet marketing : building advantage in a networked economy (2nd ed.). New York: McGraw Hill.

Rangkuti, F. (2004). Analisis SWOT teknik membedah kasus bisnis. Jakarta: Gramedia Pustaka Umum.

Rayport, J. F., \& Jaworski, B. J. (2003). Introduction to e-commerce (2nd ed.). New York: McGrawHill.

Reedy, J., Schullo, S., \& Zimmerman, K. (2000). Electronic marketing, integrating electronic resources into the marketing process. United States of America: The Dryden Press, Harcourt College Publishers.

Strauss, J., \& Frost, R. (2009). E-marketing (5th ed.). Upper Saddle, New Jersey: Prentice-Hall. 